\title{
Interferon- $\square$ Exposure of Human iPSC-derived Neurons Alters Major Histocompatibility Complex I and Synapsin I Protein Expression
}

$1 \quad$ Adam Pavlinek ${ }^{1,2}$, Rugile Matulevicute ${ }^{1,2}$, Laura Sichlinger ${ }^{1,2}$, Lucia Dutan Polit ${ }^{1,2}$, Nikolaos

2 Armeniakos $^{1,2}$, Anthony C. Vernon* ${ }^{\star 1,2}$, Deepak P. Srivastava ${ }^{\star 1,2}$

$3{ }^{1}$ Department of Basic and Clinical Neuroscience, Institute of Psychiatry, Psychology and

4 Neuroscience, King's College London, London, UK.

$5 \quad{ }^{2}$ MRC Centre for Neurodevelopmental Disorders, King's College London, London, UK.

$6 \quad{ }^{*}$ Correspondence:

7 Corresponding Author

8 anthony.vernon@kcl.ac.uk or deepak.srivastava@kcl.ac.uk

9 Keywords: Interferon- $\square_{1}, \mathbf{M H C l}_{2}$, Synapsin $\mathrm{I}_{3}, \mathrm{iPSC}_{4}$, maternal immune activation ${ }_{5}$,

10 inflammation $6 \mathbf{C A}_{7}$, schizophrenia 8

113998 words, 4 figures 


\section{Abstract}

14 Human epidemiological data links maternal immune activation during gestation with increased risk

15 for neurodevelopmental disorders including schizophrenia. Animal models of maternal immune

16 activation (MIA) provide causal evidence for this association and strongly suggest that inflammatory

17 cytokines act is a critical link between maternal infection and aberrant offspring brain and behavior

18 development. This includes evidence for reduced synapse formation, consistent with post-mortem

19 and in vivo evidence of reduced synaptic density in schizophrenia. However, to what extent specific

20 cytokines are necessary and sufficient for these effects remains unclear. Using a human cellular

21 model, we recently demonstrated that acute exposure to interferon- $\square$ (IFN $\square$ ) recapitulates molecular

22 and cellular phenotypes associated with neurodevelopmental disorders. Here, we extend this work

23 to test whether IFN $\square$ affects synapse formation in an induced neuron model that generates forebrain

24 glutamatergic neurons. Using immunocytochemistry and quantitative PCR, we demonstrate that

25 acute IFN $\square$ exposure results in significantly increased $\mathrm{MHCl}$ expression at the mRNA and protein

26 level. Furthermore, acute IFN $\square$ exposure decreases synapsin I protein in neurons but does not

27 affect synaptic gene mRNA levels. Interestingly, complement component $4 \mathrm{~A}(C 4 A) \mathrm{mRNA}$ is also

28 significantly increased following acute IFN $\square$ exposure. This study builds on our previous work by

29 showing that IFN $\square$-mediated disruption of relevant synaptic proteins can occur at early stages of

30 synapse formation, potentially contributing to neurodevelopmental disorder phenotypes such as

31 schizophrenia. 


\section{Introduction}

33 Human epidemiological studies and animal models suggest a link between maternal immune

34 activation (MIA) and an increased risk for psychiatric disorders with a putative neurodevelopmental

origin, including schizophrenia (Kępińska et al., 2020). Although there are likely to be many plausible

factors that are critical for establishing neurodevelopmental resilience or susceptibility to MIA

37 (Meyer, 2019), there is evidence to suggest that the intensity of the maternal immune response is an

38 important factor linking maternal infection to abnormal brain development and behavioural

39 phenotypes (Mueller et al., 2018;Mueller et al., 2019;Estes et al., 2020). MIA models present with

40 deficits in cognitive and social behaviours (Mueller et al., 2021), which are accompanied by altered

41 synaptic plasticity, decreased synaptic protein levels, and reduced dendritic spine density,

42 predominantly in the prefrontal cortex and hippocampus (Coiro et al., 2015;Weir et al., 2015;Zhang

43 and van Praag, 2015;Giovanoli et al., 2016;Pekala et al., 2021). These findings are consistent with

44 in vivo neuroimaging evidence for reduced synaptic density, as measured by SV2A-PET in

45 schizophrenia (Onwordi et al., 2020), reduced dendritic spines (Glantz and Lewis, 2000), and

46 decreased expression of synaptic proteins in post-mortem brain tissue from individuals with

47 schizophrenia (Osimo et al., 2019).

49 One key feature of the maternal immune response that shapes these phenotypes is the elevation of

50 numerous cytokines in the maternal serum, placenta and foetal brain (Urakubo et al., 2001;Garay et

51 al., 2013). Consistent with this view, elevated cytokine levels in maternal serum are predictive for the

52 risk of offspring developing schizophrenia (Allswede et al., 2020). Moreover, human birth cohort

53 studies provide evidence that variation in maternal cytokine levels during pregnancy are associated

54 with offspring cognitive and behavioral outcomes, as well as measures of fetal brain growth and connectivity as measured by MRI (Graham et al., 2018;Rudolph et al., 2018;Rasmussen et al., 2021). Collectively, these studies suggest that changes in maternal cytokines during pregnancy can 
58 these effects remains unclear, and the underlying molecular mechanisms remain to be fully

59 elucidated. Evidence from animal models of MIA provides strong support for the involvement of

60 interleukins, particularly IL-6, but also TNF-alpha, IL-1beta, IL-10 and interferon- $\square$ (IFN $\square$ ) (Smith et

61 al., 2007; Lins et al., 2018;Mirabella et al., 2021;Mueller et al., 2021). IFN $\square$ has been found to have

62 increased levels in the plasma of first-episode schizophrenia patients (Lesh et al., 2018). However, it

63 is unclear whether and how this is contributing to increased risk for schizophrenia. In addition to its

64 key role in the response to viral infection, IFN $\square$ has also been shown to induce retraction of

65 dendrites and inhibit synapse formation in the central nervous system (Kim et al., 2002;Monteiro et

66 al., 2017).

68 We previously showed that exposure of neural progenitor cells (NPCs) and developing immature

69 neurons derived from human induced pluripotent stem cells (iPSCs) to IFN $\square$ results in gene

70 expression changes in genes associated with schizophrenia and autism, and altered neuronal

71 morphology, with increased outgrowth in exposed neurons (Warre-Cornish et al., 2020). In

72 particular, IFN $\square$ treatment increases major histocompatibility complex I (MHCl) expression (Warre-

73 Cornish et al., 2020). Class I MHC family molecules are best known for their function in presenting

74 antigens to T-cells (Shatz, 2009). $\mathrm{MHCl}$ is expressed in neurons and neural progenitors and has

75 been found to be important in neuronal plasticity and for the co-regulation of synapse pruning in

76 mice (Shatz, 2009; Lee et al., 2014). MHCl negatively regulates synapse density in developing

77 cortical neurons, with in vitro manipulations of $\mathrm{MHCl}$ expression inversely affecting the density of

both GABAergic and glutamatergic synapses in rat and mouse cultures (Glynn et al., 2011). In a

mouse model of MIA, synapse number in cultured cortical neurons was decreased, and $\mathrm{MHCl}$ was

80 found to be required for this MIA-induced effect on synapse density (Elmer et al., 2013). However, it

81 is not known if cytokine-driven increases in $\mathrm{MHCl}$ impact synapse formation in human neurons.

82 Genome-wide association studies also support the MHC loci links with schizophrenia (Shi et al.,

83 2009;Ripke et al., 2014). For example, variation of complement component 4 (C4) at the MHCIII 
84 locus and human leukocyte antigen-B (HLA-B) at the $\mathrm{MHCl}$ locus is strongly associated with

85 increased risk for schizophrenia (Sekar et al., 2016).

87 In our previous work, gene expression changes following IFN $\square$ treatment included increased

expression of $\mathrm{MHCl}$ genes and downregulation of synapse-related genes in exposed iPSC-derived immature neurons (Warre-Cornish et al., 2020). Given that IFN $\square$ has been shown to affect expression of synaptic genes in iPSC-neurons in the absence of glial cells (Warre-Cornish et al., 2020), we wanted to determine whether the Neurogenin 2 optimized inducible overexpression ioGlutamatergic cell line (Pawlowski et al., 2017) could be a useful system for studying the effects of

93 IFN $\square$ in a pure population of glutamatergic cells. Using this system, we aim to further characterize

94 the effect of IFN $\square$ treatment on $\mathrm{MHCl}$ expression and synapses. We find that IFN $\square$ exposure 95 increases $\mathrm{MHCl}$ protein staining and $H L A-B$ and $C 4 A$ expression but decreases the synaptic protein 96 synapsin I in cell bodies without altering the expression of synaptic genes.

\section{$97 \quad 1 \quad$ Methods}

\subsection{HiPSC culture, neuralization, and treatment}

99 The ioGlutamatergic male neurotypical stem cell line (Pawlowski et al., 2017) was obtained from

100 BitBio (Cambridge, UK) under MTA agreement. ioGlutamatergic cells were maintained in Stemflex 101 media (Gibco; A3349401) on six-well plates coated with 1:100 Geltrex (Life technologies; 102 A1413302). Media was changed every 48 hours and passaged when $70-80 \%$ confluent with HBSS 103 and Versene (Gibco; 15040066) at $37^{\circ} \mathrm{C}$ before being transferred into new Stemflex medium. 104 Neuralization was conducted based on the protocol used by Pawlowski et al. (2017). Cells for 105 experiments were terminally plated onto 6-well plates (for RNA extraction) or glass coverslips in 24106 well plates (for immunocytochemistry) coated with Poly-D-Lysine (5 $\mu \mathrm{g} / \mathrm{ml}$, PDL, A-003-E; Millipore) 107 and laminin (1 mg/ml Sigma L2020). iPSCs were dissociated with accutase (A11105-01; Thermo 108 Fisher Scientific) before being diluted with medium and subsequently resuspended in N2 medium 
109 (supplementary table 1) with $1 \mu \mathrm{g} / \mathrm{ml}$ doxycycline hyclate and $10 \mu \mathrm{M}$ ROCK inhibitor (Sigma; Y0503).

110 Cells were plated at a density of 900,000 cells/well for RNA extraction and 25,000 cells/well for ICC.

111 The cells were incubated at $37^{\circ} \mathrm{C} ; 5 \% \mathrm{CO} ; 20 \% \mathrm{O} 2$ with daily $\mathrm{N} 2$ media changes supplemented

112 with $1 \mu \mathrm{g} / \mathrm{ml}$ doxycycline hyclate. $25 \mathrm{ng} / \mathrm{ml}$ IFN $\square$ (Abcam, AB9659; diluted in DMEM) for treatment

113 conditions or vehicle (DMEM) was added at day 3 to the N2 medium. The cells were incubated for

114 24-hours before sample collection (Warre-Cornish et al., 2020).

115 The 127_CTM_01 iPSC male neurotypical line (Adhya et al., 2021) was differentiated into NPCs

116 using a dual SMAD inhibition protocol (Shum et al., 2020;Adhya et al., 2021). Briefly, the NPCs were

117 expanded from day 18 frozen stocks in maintenance medium (1:1 N2:B27, 10ng/ml bFGF) for seven

118 days. Before treatments the cells were plated on 12-well NUNC ${ }^{\mathrm{TM}}$ tissue culture plates (Thermo

119 Scientific; 150628) at a density of 500,000 cells/well, with dedicated wells for treatment and vehicle

120 treatments. The day after plating, the cells were exposed to $25 \mathrm{ng} / \mathrm{ml}$ IFNy or vehicle and incubated

121 for 24-hours before sample collection.

\section{$122 \quad 1.2$ Immunocytochemistry}

123 Cells were fixed with 4\% formaldehyde in PBS-sucrose for 10 minutes at room temperature, washed

$1242 \times$ with Dulbecco's PBS (DPBS, Gibco), and then fi xed with ice cold Methanol at $4^{\circ} \mathrm{C}$ for 10

125 minutes, then washed $2 \times$ with DPBS. Cells were permeabilized and blocked using $2 \%$ normalized

126 goat serum (NGS) in DPBS with $0.1 \%$ triton $x-100$ for 2 hours. Antibody solutions (supplementary

127 table 2) were prepared in $2 \%$ NGS in DPBS. The coverslips were incubated with primary antibody

128 solution at $4^{\circ} \mathrm{C}$ overnight, then washed $3 \times$ with DPBS for 10 minutes each and incubated with

129 secondary antibodies for 1 hour at room temperature. The coverslips were washed $3 \times$ with DPBS for

13010 minutes each and incubated for 5 minutes in DAPI solution, followed by two DPBS washes, then

131 mounted onto glass slides using ProLong Gold antifade reagent (Invitrogen P36930).

\section{$132 \quad \mathbf{1 . 3}$ Microscopy and image analysis}


133 Coverslips were imaged using a Leica SP5 confocal microscope. The gain and other imaging

134 parameters were set using the vehicle control and were not changed during subsequent imaging of

135 the control and IFN $\square$ exposed coverslips. $246.5 \times 246.5 \mu \mathrm{m}$ regions were imaged. The $\mathrm{Z}$ stack

136 thickness was kept at $0.5 \mu \mathrm{m}$. Z stacks were maximally projected to form a single image in FIJI.

137 Prior to measuring fluorescent intensity, the background of each image and channel was measured

138 in FIJI by selection of $1025 \times 25$-pixel areas of background and by then measuring the mean

139 intensity and standard deviation (SD) of intensity of each area. The mean of these measurements +

140 2SD was then subtracted from the image. Cell Profiler (Carpenter et al., 2006) was used to identify

141 the nuclei, cells, cell bodies, processes, and the cytoplasm and to measure the mean intensity of the

$142 \mathrm{MHC}$ and synapsin I channels. Mean intensity values of 0 were excluded from the analysis. The

143 pipeline is provided as a supplementary file.

\section{$144 \quad 1.4$ Quantitative PCR}

145 Cells for RNA extraction were lysed in TRI Reagent (T3809, Merck) for 5 minutes at room 146 temperature and RNA was extracted from TRI Reagent according to the manufacturer's protocol.

147 Isolated RNA was cleaned by precipitation with $3 \%$ sodium acetate in ethanol at $-80^{\circ} \mathrm{C}$ overnight,

148 washed as in the isolation protocol, and resuspended in $\mathrm{H}_{2} \mathrm{O}$. A nanodrop spectrophotometer was 149 used to measure RNA concentration and quality.

151 For cDNA synthesis, a mixture of $1 \mu$ l of oligo(dT)20 (50 $\mu \mathrm{M})$ (Invitrogen; 18418020), $2 \mu \mathrm{g}$ total RNA, $1521 \mu \mathrm{l} 10 \mathrm{mM}$ dNTP Mix (10 mM each) (Invitrogen; 18427013), and water to make up a total of $13 \mu \mathrm{l}$ per 153 sample was heated to $65^{\circ} \mathrm{C}$ for 5 minutes and incubated on ice for one minute. Next, superscript 154 mastermix (Invitrogen; 18080093) was added to each sample $(4 \mu \mathrm{l}$ X First-Strand Buffer, $1 \mu \mathrm{l} 0.1 \mathrm{M}$ 155 DTT, $1 \mu$ I RNaseOUT Recombinant RNase Inhibitor (Invitrogen; 10777019), $1 \mu$ l of SuperScript III RT $156(200$ units $/ \mu \mathrm{l}))$ and the mixture was incubated at $50^{\circ} \mathrm{C}$ for 50 minutes and then $70^{\circ} \mathrm{C}$ for 15 minutes. 157 qPCR was done in a 348 well plate, with two technical replicates per sample, and also a blank well 158 containing no cDNA for each primer pair. Three housekeeping genes (HPRT, SDHA, RPL27) were 
used. Primer sequences are provided in the supplementary material. A mastermix consisting of $2 \mu \mathrm{l}$

$1605 x$ qPCR Mix Plus, $1.5 \mu$ l Primer mix, and $4.5 \mu$ l RNAse free per well was added to the plate. $2 \mu l$

161 cDNA were added to each well. qPCR was run using a QuantStudio7 thermocycler with one cycle

162 for 12 minutes at $95^{\circ} \mathrm{C}$ and 40 cycles of $95^{\circ} \mathrm{C}$ for $15 \mathrm{~s}, 60-65^{\circ} \mathrm{C}$ for $20 \mathrm{~s}$ and $72^{\circ} \mathrm{C}$ for $20 \mathrm{~s}$.

163

164 The data were analysed using the $2^{-\Delta \Delta \mathrm{Ct}}$ method (Livak and Schmittgen, 2001). For each gene, the

165 technical replicates were averaged. The three housekeeping genes were averaged and the $\Delta \mathrm{Ct}$

166 (difference between the housekeeper average and gene of interest average) was calculated for

167 each gene of interest. The $\Delta \Delta \mathrm{Ct}$ was calculated as $\Delta \mathrm{Ct}$-[Calibrator] where the calibrator is the

168 average of the $\Delta \mathrm{Ct}$ of the controls. The final result is $2^{-\Delta \Delta \mathrm{Ct}}$. This value was log-transformed prior to

169 statistical analysis.

\section{$170 \quad 1.5$ Statistical analysis}

171 For both the ICC and qPCR experiments, three biological replicates $(\mathrm{N}=3)$ were analysed, where

172 each replicate is the same cell line but with a different passage number and differentiated on a

173 different day. The number of replicates was decided prior to the conducting of the experiments.

174 Statistical analysis was done in Prism 9.0.2. The exposed and control mean intensity values (ICC) or

$175 \log \left(2^{-\Delta \Delta C t}\right)$ values $(\mathrm{qPCR})$ were compared using multiple 2-tailed unpaired t-tests, corrected for

176 multiple comparisons (Holm-Šídák method). $\mathrm{P}=0.05$ was used as the threshold value for statistical

177 significance.

$178 \quad 2 \quad$ Results

1792.1 Acute IFNy exposure downregulates presynaptic genes associated with synaptic $180 \quad$ vesicles

181 In the RNA sequencing data from our previous study, we found downregulation of genes related to

182 the GO term "synapses" in iPSC-derived immature neurons exposed to IFNy for 24 hours (Warre-

183 Cornish et al., 2020). To explore this further, a curated database of synaptic genes, SynGO 
184 (Koopmans et al., 2019), was used to identify significantly enriched biological processes (BP) and

185 cellular component (CC) ontologies related to synaptic function. Analyses were carried out with the

186 complete list of significantly down-regulated genes in immature neurons acutely exposed to IFNy (25

$187 \mathrm{ng} / \mathrm{ml}, 24$ hours) compared with vehicle-exposed neurons. The results reveal 18 genes mapping to

188 SynGO synaptic proteins with significant enrichment for 3 CC and 5 BP terms (Figure 1). Most of

189 these proteins $(n=12)$ were annotated in the presynapse cluster with 4 genes enriched for the

190 synaptic vesicle membrane term. These results suggest that acute IFNy exposure leads to the

191 downregulation of 18 genes that exert presynaptic functions and regulate synaptic vesicle

192 mechanisms in immature neurons.

\section{$193 \quad 2.2 \quad$ Ngn2 overexpression generates early glutamatergic neurons at day 4}

194 We used ioGlutamatergic line cells with NGN2 optimized inducible overexpression to allow for rapid

195 and reliable generation of NGN2-induced neurons (NGN2-iNs) upon treatment with doxycycline

196 (Zhang et al., 2013;Pawlowski et al., 2017). We first validated whether the ioGlutamatergic line

197 expresses relevant markers of glutamatergic neurons after the activation of the NGN2 gene. By day

1987 of differentiation, the cells express the pan-neuronal marker microtubule-associated protein 2

199 (MAP2) and excitatory presynaptic marker vesicular glutamate transporter 1 (VGLUT1)

200 (Supplementary Figure 1). After 28 days of differentiation $>99 \%$ of DAPI+ cells were immune-

201 positive for MAP2 and also expressed TBR1, VGLUT1, CAMKIIA, and SV2A, consistent with the

202 generation of forebrain glutamatergic neurons (Supplementary Figure 2). This is consistent with

203 evidence that the majority of mature ioGlutamatergic neurons represent cortical excitatory neurons

204 (Zhang et al., 2013;Lin et al., 2021). Analysis was conducted on cells at day 4 of differentiation,

205 hereafter referred to as Day 4 NGN2-iNs. At this developmental timepoint, the NGN2-iNs generate

206 developing immature neurons (Lin et al., 2021), consistent with the iPSC-neurons used in our

207 previous studies (Warre-Cornish et al., 2020). 
209 We characterized Day 4 NGN2-iNs using immunocytochemistry (ICC) and quantitative PCR (qPCR).

210 We stained for the post-mitotic neuron marker neuronal nuclei antigen $(\mathrm{NeuN})$ and mature neuron

211 marker microtubule-associated protein 2 (MAP2) and the neuroprogenitor markers nestin (NES) and

212 PAX6. In addition, staining was conducted for the immature neuron/late progenitor marker Class III

$213 \beta$-Tubulin (TUBB3). Qualitatively, all imaged Day 4 NGN2-iNs expressed both the neuroprogenitor

214 markers nestin and PAX6 and the neuronal markers NeuN and MAP2 (Supplementary Figure 3),

215 indicating that the Day 4 NGN2-iNs represent early post-mitotic neurons. Morphologically, Day 4

216 cells had extensive processes, with some resembling developing neurons with a pyramidal cell

217 body. Other cells had a bipolar immature morphology (Supplementary Figure 3).

219 qPCR for the neuronal markers NeuN, TBR1, and MAP2 and the neuroprogenitor markers nestin

220 and PAX6 (Supplementary Figure 3) revealed that neural genes had a higher expression level

221 compared to the progenitor genes; in particular TBR1 and NeuN were highly expressed. Overall,

222 these results indicate that Day 4 NGN2-iNs resemble developing immature neurons.

\subsection{Acute exposure of Opti-OX neurons to IFN $\square$ results in increased $\mathrm{MHCl}$ in the whole cell}

\section{but decreased synapsin I in the cell body}

Given the effects of IFN $\square$ on synaptic genes and particularly on synaptic vesicle mechanisms, we next directly tested the effect of acute IFN $\square$ exposure on synapsin 1, a synaptic vesicle regulator, in

Day 4 NGN2-iNs. Synapsin I was selected as an early synaptic marker, since this protein is expressed in NPCs and colocalizes with constitutively recycling vesicles along the whole surface of developing axons that then localize to forming synapses (Zakharenko et al., 1999;Bonanomi et al., 230 2005).

231 To test how acute exposure to IFN $\square$ affects $\mathrm{MHCl}$ and synapsin I expression, NGN2-iNs were 232 exposed to IFN $\square(25 \mathrm{ng} / \mathrm{ml})$ or a vehicle control at day 3 for 24 hours (Figure $2 \mathrm{~A})$. We next asked 233 whether these cells expressed $\mathrm{MHCl}$ at day 4 because $\mathrm{MHCl}$ has previously been used as a 234 readout for the effect of IFN $\square$ treatment (Warre-Cornish et al., 2020). MHCI was localised to the cell 
body, processes, and growth cones of all Day 4 NGN2-iNs (Figure 2C). All cells expressed MHCI to

a similar degree. Interestingly, in all the neurons there were also bright $\mathrm{MHCl}$ puncta in the nucleus (Figure 2B).

238

Synapsin I staining was localised to the cell body, processes, and growth cones (Figure 3B). Staining was particularly bright in the cell body, with synapsin I asymmetrically localized within the shaft of one process in many neurons (Figure 3A), presumably in vesicles being transported to the processes (Figure 3A, arrowhead). Unlike $\mathrm{MHCl}$, synapsin I did not localise to the nucleus and was instead at the surface of the cell within the cytoplasm. There were also sparse puncta of synapsin I along cell processes. Expression of synapsin I at day 4 is thus primarily in the cell body of all cells.

To analyze changes in $\mathrm{MHCl}$ and synapsin I intensity, we designed a custom CellProfiler (Carpenter et al., 2006) pipeline to measure intensity in whole cells, nuclei, cell bodies, processes, and the cytoplasm. The IFN $\square$-exposed Day 4 NGN2-iNs had a visibly higher intensity of $\mathrm{MHCl}$ staining compared to the control (Figure 2C). There appeared to be increased intensity of $\mathrm{MHCl}$ in the cell body and increased $\mathrm{MHCl}$ localization to the processes in the IFN $\square$-exposed neurons (Figure 2C). Cell profiler analysis confirmed that the mean $\mathrm{MHCl}$ intensity was increased by $31.2 \%$ in the cells as a whole $\left(t_{(43)}=2.920, P<0.0001\right)$, increased in the cytoplasm by $56.3 \% \quad\left(t_{(40)}=4.723, P<0.0001\right)$, processes by $52.5 \%\left(\mathrm{t}_{(43)}=4.331, \mathrm{P}<0.0001\right)$, and cell body by $34.6 \%\left(\mathrm{t}_{(40)}=3.819, \mathrm{P}=0.0005\right)$ (Figure $2 \mathrm{D}-\mathrm{H}) . \mathrm{MHC} \mathrm{I}$ intensity in the nucleus was not significantly different $\left(\mathrm{t}_{(43)}=1.937, \mathrm{P}=0.06\right)($ Figure $2 \mathrm{H})$.

255

In contrast, synapsin I appeared to be decreased in IFN $\square$-exposed neurons. Specifically, the asymmetrically localized clusters of synapsin I vesicles in the shaft and cell body seemed reduced in some exposed neurons, while others had intensity that is similar to control neurons (Figure 3B). Quantification showed that synapsin I intensity was decreased in the whole cell by $21.6 \%$ $260 \quad\left(t_{(43)}=2.303, P=0.0261\right)$, cell body by $23.7 \% \quad\left(t_{(43)}=2.300, P=0.0263\right)$, and cytoplasm by $31.1 \%$ $261\left(\mathrm{t}_{(43)}=3.339, \mathrm{P}=0.0017\right)$ (Figure $\left.3 \mathrm{C}-\mathrm{F}\right)$. The mean intensity difference in IFN $\square$-exposed processes 
262 was not statistically significant $\left(t_{(43)}=1.840, P=0.0726\right.$, unpaired t-test) (Figure $\left.3 E\right)$. Since synapsin I

263 does not localize to the nucleus, nuclear intensity was not analysed. These results show that IFN $\square$

264 increases $\mathrm{MHCl}$ in Day 4 NGN2-iNs but has an inverse effect on synapsin I, which decreases in the

265 cytoplasm and cell body. Cytoplasmic synapsin I and $\mathrm{MHCl}$ intensities in single cells are positively

266 correlated in the vehicle condition $(r=0.57, n=306)$, which did not change $(P=0.1471, z=1.45)$ in the

267 IFN $\square$-exposed condition ( $r=0.49, \mathrm{n}=389)$.

2.4 C4A and HLA-B mRNA is upregulated in IFN $\square$-exposed neurons, but synaptic gene expression is unaltered

270 To validate our findings of increased $\mathrm{MHCl}$ staining in IFN $\square$-exposed NGN2-iNs, we measured 271 expression of $H L A-B$ and $H L A-C$ using qPCR. We also measured expression of the receptors for

272 IFN $\square$, IFNGR1 and IFNGR2, and C4A expression. Of these, only $H L A-B\left(\mathrm{t}_{(4)}=27.97, \mathrm{P}=0.00001\right)$ and

$273 C 4 A$ expression $\left(\mathrm{t}_{(4)}=11.84, \mathrm{P}=0.000291\right)$ were significantly increased in the exposed neurons

274 (Figure 4A).

275 Since synapsin I decreases in the cell body following IFN $\square$ treatment, we tested whether expression

276 of synapsin I and other synaptic genes would be decreased following IFN $\square$ treatment. The mean

277 expression level for SYN1, DLG4, SV2A, and GRIN1 were not significantly different (Figure 4A). We

278 confirmed these findings using NPCs generated from a control iPSC line using a dual SMAD

279 inhibition differentiation protocol. NPCs were exposed to IFN $\square$ for 24 hours. $H L A-B\left(\mathrm{t}_{(4)}=22.53\right.$,

$280 \mathrm{P}=0.000023)$ and $C 4 A$ expression $\left(\mathrm{t}_{(4)}=6.466, \mathrm{P}=0.002947\right)$ were significantly increased in the

281 exposed NPCs (Figure 4B), which matches results from the exposed NPC-like NGN2-iNs.

\section{$283 \quad$ Discussion}

284 In this study, we used NGN2-iNs (ioGlutamatergic line; BitBio inc) and acute IFN $\square$ exposure to show 285 how synaptic protein expression can be disrupted by this cytokine. We built on studies showing 
IFN $\square$ affects expression of synaptic genes in iPSC-derived immature neurons (Warre-Cornish et al., 2020).

In an acute IFN $\square$ exposure experiment, we observed that synapsin I intensity decreased while HLA

increased density of clusters of synaptic vesicles with synapsin I upon siRNA knockdown of an

$\mathrm{MHCl}$ subunit and observed significantly decreased synapsin I at inhibitory synapses when $\mathrm{MHCl}$

was overexpressed in rodent neurons. The decreased synapsin I we observed is thus likely linked to

294 the concurrently increased $\mathrm{MHCl}$ expression, although we observed a positive correlation between

synapsin I and $\mathrm{MHCl}$ intensity at the single-cell level. Decreased synapsin may translate to

disruptions in synapses subsequently, as synapsin I is important for synapse maturation, including

297 the correct localisation of synaptic vesicles in growth cones and the regulation of vesicle recycling

298 rate (Bonanomi et al., 2005). A gene enrichment study comparing both rat (gestational day 15, LPS

299 MIA) whole-brain and post-mortem human brain tissue samples from individuals with autism

300 reported a common downregulation of genes associated with synaptic vesicle exocytosis (Lombardo

301 et al., 2018). This is in line with our SynGO analysis of our IFN $\square$ RNAseq dataset (Warre-Cornish et

302 al., 2020) and the decrease in synapsin I associated with synaptic vesicles observed here. Whether

303 these changes in synaptic protein translate to altered neuronal activity remains to be established. A

304 previous study suggested that IFN $\square$ treatment of cultured early hippocampal mouse (E15) neurons

305 at 1-4 days in vitro has no effect on excitatory transmission, however it did not investigate other

synapse parameters nor whether treatment of NPCs has an effect (Mirabella et al., 2021).

307

308 We did not see any difference in gene expression of our selected synaptic genes. This can be due

309 to several possibilities. There may be changes in synapsin I translation, mRNA turnover, expression

310 of splice variants, or misregulation of genes associated with synapsin I. Expressed protein reflects

311 an earlier time point than mRNA expression, the absence of any difference in mRNA levels could

312 therefore also indicate a transient change in expression that is no longer detectable after 24 hours. 
313 The synapsin I intensity change observed may also reflect changes in the spatial distribution of

314 synaptic proteins or in local translation, which is not detectable in whole-cell RNA.

316 The increase in $\mathrm{MHCl}$ expression and staining intensity following IFN $\square$ exposure matches the

317 findings of a previous neuroprogenitor cell study that used the same 24 hour acute IFN $\square$ exposure

318 of iPSC-NPCs and -neurons (Warre-Cornish et al., 2020). In this study, Warre-Cornish et al. (2020)

319 found persistent upregulation of $\mathrm{MHCl}$ gene expression and increased $\mathrm{MHCl}$ protein levels. They

320 also described upregulation of $H L A-C$ and $H L A-B$ expression; however, we only observed a

321 significant increase in $H L A-B$. As in the study, we observed no change in the expression of IFN $\square$

322 receptors. $\mathrm{MHCl}$ is known to be involved in synaptic plasticity and learning (Datwani et al.,

323 2009;Shatz, 2009; Lee et al., 2014;Adelson et al., 2016) and is important for negatively regulating

324 synapses (McAllister, 2014). Dysregulation of $\mathrm{MHCl}$ expression could thus potentially be sufficient

325 for a downstream disruption of synapses even if no change in synaptic genes is present at the point

326 of IFN $\square$ exposure. MHCI has been shown to mediate reduced synaptic connectivity in a mouse MIA

327 model by signalling through myocyte enhancer factor 2 (MEF2) (Elmer et al., 2013). Future work

328 would need to establish whether these changes in $\mathrm{MHCl}$ expression persist and whether other

329 downstream changes arise as the neurons mature.

330

331 We also observed increased expression of the complement component $C 4 A$ after acute IFN $\square$

332 exposure, in line with Warre-Cornish et al. (2020). C4A mRNA levels are increased in post-mortem

333 schizophrenia patient brains and C4A variants are associated with schizophrenia risk (Sekar et al.,

334 2016). Genes downregulated upon increased C4A expression are enriched for schizophrenia risk

335 (Kim et al., 2021). C4A is expressed by neurons and colocalizes with synaptic markers and is

336 thought to mediate pruning of synapses (Sekar et al., 2016). Overexpression of C4A in mice

337 resulted in behavioural changes, reduced cortical synapse density, and increased engulfment of

338 synapses by microglia (Yilmaz et al., 2021). Inhibition of microglial activity reverses MIA

339 abnormalities, including synapse loss (Ikezu et al., 2021). Increased C4A expression could therefore 
bioRxiv preprint doi: https://doi.org/10.1101/2021.12.15.472810; this version posted December 16,2021 . The copyright holder for this preprint (which was not certified by peer review) is the author/funder, who has granted bioRxiv a license to display the preprint in perpetuity. It is made

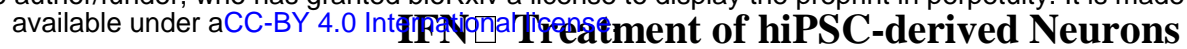

340 contribute to decreased synapse number. Co-culture studies with microglia would be particularly 341 informative for future IFN $\square$ exposure studies.

342

343 The ioGlutamatergic cell line provides a good system for future IFN $\square$ exposure studies of neurons.

344 Our findings suggest a possible link between IFN $\square$ exposure and reduced synaptic vesicles in early

345 neurons, potentially via $\mathrm{MHCl}$, however more work is needed to understand the basis of this link. 


\section{Conflict of Interest}

347 The authors declare that the research was conducted in the absence of any commercial or financial

348 relationships that could be construed as a potential conflict of interest.

\section{$3495 \quad$ Author Contributions}

350 DPS and ACV: conception and design, literature searching, manuscript writing and editing and

351 project supervision. AP, RM, LS, LDP and NA: carried out experiments. AP: manuscript writing and

352 editing. DPS and ACV: financial support. All authors approved the final manuscript.

\section{$353 \quad 6 \quad$ Funding}

354 AP, DPS and ACV acknowledge financial support for this study from the Medical Research Council (MRC) Centre grant (MR/N026063/1). AP and RM are in receipt of the MRC-Sackler PhD Programme studentship as part of the MRC Centre for Neurodevelopmental Disorders (Medical

357 Research Council MR/P502108/1). LS is supported by the UK Medical Research Council 358 (MR/N013700/1) and King's College London member of the MRC Doctoral Training Partnership in

359 Biomedical Sciences; LDP is supported by a research grant from the University of Pennsylvania 360 Autism Spectrum Program of Excellence awarded to DPS. DPS was also supported by an

361 Independent Researcher Award from the Brain and Behavior Foundation (formally National Alliance 362 for Research on Schizophrenia and Depression (NARSAD) (Grant No. 25957). ACV acknowledges

363 financial support for this study from the National Centre for the Replacement, Refinement and

364 Reduction of Animals in Research (NC/S001506/1).

\section{Acknowledgments}

366 The authors thank Daniel Beglin for his insightful comments on image analysis. The authors also 367 thank the Wohl Cellular Imaging Centre (WCIC) at the loPPN, Kings College, London, for help with 368 microscopy. 


\section{References}

371

372

Adelson, J.D., Sapp, R.W., Brott, B.K., Lee, H., Miyamichi, K., Luo, L., Cheng, S., Djurisic, M., and Shatz, C.J. (2016). Developmental Sculpting of Intracortical Circuits by MHC Class I H2-Db and H2-Kb. Cerebral Cortex 26, 1453-1463.

Adhya, D., Swarup, V., Nagy, R., Dutan, L., Shum, C., Valencia-Alarcón, E.P., Jozwik, K.M., Mendez, M.A., Horder, J., Loth, E., Nowosiad, P., Lee, I., Skuse, D., Flinter, F.A., Murphy, D., Mcalonan, G., Geschwind, D.H., Price, J., Carroll, J., Srivastava, D.P., and Baron-Cohen,

Allswede, D.M., Yolken, R.H., Buka, S.L., and Cannon, T.D. (2020). Cytokine concentrations throughout pregnancy and risk for psychosis in adult offspring: a longitudinal case-control

Bonanomi, D., Menegon, A., Miccio, A., Ferrari, G., Corradi, A., Kao, H.-T., Benfenati, F., and Valtorta, F. (2005). Phosphorylation of Synapsin I by cAMP-Dependent Protein Kinase

Carpenter, A.E., Jones, T.R., Lamprecht, M.R., Clarke, C., Kang, I.H., Friman, O., Guertin, D.A., Controls Synaptic Vesicle Dynamics in Developing Neurons. The Journal of Neuroscience $25,7299-7308$.

Coiro, P., Padmashri, R., Suresh, A., Spartz, E., Pendyala, G., Chou, S., Jung, Y., Meays, B., Roy, S., Gautam, N., Alnouti, Y., Li, M., and Dunaevsky, A. (2015). Impaired synaptic 
development in a maternal immune activation mouse model of neurodevelopmental disorders. Brain Behav Immun 50, 249-258.

Datwani, A., Mcconnell, M.J., Kanold, P.O., Micheva, K.D., Busse, B., Shamloo, M., Smith, S.J., and Shatz, C.J. (2009). Classical MHCI molecules regulate retinogeniculate refinement and limit ocular dominance plasticity. Neuron 64, 463-470.

Elmer, B.M., Estes, M.L., Barrow, S.L., and Mcallister, A.K. (2013). MHCI requires MEF2 transcription factors to negatively regulate synapse density during development and in disease. J Neurosci 33, 13791-13804.

Estes, M.L., Prendergast, K., Macmahon, J.A., Cameron, S., Aboubechara, J.P., Farrelly, K., Sell, G.L., Haapanen, L., Schauer, J.D., Horta, A., Shaffer, I.C., Le, C.T., Kincheloe, G.N., Tan, D.J., Van Der List, D., Bauman, M.D., Carter, C.S., Van De Water, J., and Mcallister, A.K. (2020). Baseline immunoreactivity before pregnancy and poly(l:C) dose combine to dictate susceptibility and resilience of offspring to maternal immune activation. Brain Behav Immun $88,619-630$.

Garay, P.A., Hsiao, E.Y., Patterson, P.H., and Mcallister, A.K. (2013). Maternal immune activation causes age- and region-specific changes in brain cytokines in offspring throughout development. Brain Behav Immun 31, 54-68. immune activation causes hippocampal synaptic deficits in the absence of overt microglia

Glantz, L.A., and Lewis, D.A. (2000). Decreased dendritic spine density on prefrontal cortical pyramidal neurons in schizophrenia. Arch Gen Psychiatry 57, 65-73.

415 Glynn, M.W., Elmer, B.M., Garay, P.A., Liu, X.-B., Needleman, L.A., El-Sabeawy, F., and Mcallister, 416 A.K. (2011). $\mathrm{MHCl}$ negatively regulates synapse density during the establishment of cortical connections. Nature neuroscience 14, 442-451. 
Graham, A.M., Rasmussen, J.M., Rudolph, M.D., Heim, C.M., Gilmore, J.H., Styner, M., Potkin, S.G., Entringer, S., Wadhwa, P.D., Fair, D.A., and Buss, C. (2018). Maternal Systemic Interleukin-6 During Pregnancy Is Associated With Newborn Amygdala Phenotypes and Subsequent Behavior at 2 Years of Age. Biol Psychiatry 83, 109-119.

Ikezu, S., Yeh, H., Delpech, J.C., Woodbury, M.E., Van Enoo, A.A., Ruan, Z., Sivakumaran, S., You, Y., Holland, C., Guillamon-Vivancos, T., Yoshii-Kitahara, A., Botros, M.B., Madore, C., Chao, P.H., Desani, A., Manimaran, S., Kalavai, S.V., Johnson, W.E., Butovsky, O., Medalla, M., Luebke, J.I., and Ikezu, T. (2021). Inhibition of colony stimulating factor 1 receptor corrects maternal inflammation-induced microglial and synaptic dysfunction and behavioral abnormalities. Mol Psychiatry 26, 1808-1831.

Kępińska, A.P., lyegbe, C.O., Vernon, A.C., Yolken, R., Murray, R.M., and Pollak, T.A. (2020). Schizophrenia and Influenza at the Centenary of the 1918-1919 Spanish Influenza Pandemic: Mechanisms of Psychosis Risk. Front Psychiatry 11, 72.

Kim, I.-J., Beck, H.N., Lein, P.J., and Higgins, D. (2002). Interferon y Induces Retrograde Dendritic Retraction and Inhibits Synapse Formation. The Journal of Neuroscience 22, 4530-4539. La Torre-Ubieta, L., and Gandal, M.J. (2021). Brain gene co-expression networks link complement signaling with convergent synaptic pathology in schizophrenia. Nat Neurosci 24,

Koopmans, F., Van Nierop, P., Andres-Alonso, M., Byrnes, A., Cijsouw, T., Coba, M.P., Cornelisse, L.N., Farrell, R.J., Goldschmidt, H.L., Howrigan, D.P., Hussain, N.K., Imig, C., De Jong, A.P.H., Jung, H., Kohansalnodehi, M., Kramarz, B., Lipstein, N., Lovering, R.C., Macgillavry, H., Mariano, V., Mi, H., Ninov, M., Osumi-Sutherland, D., Pielot, R., Smalla, K.H., Tang, H., Tashman, K., Toonen, R.F.G., Verpelli, C., Reig-Viader, R., Watanabe, K., Van Weering, J., Achsel, T., Ashrafi, G., Asi, N., Brown, T.C., De Camilli, P., Feuermann, M., Foulger, R.E., Gaudet, P., Joglekar, A., Kanellopoulos, A., Malenka, R., Nicoll, R.A., Pulido, C., De Juan- 
Sanz, J., Sheng, M., Südhof, T.C., Tilgner, H.U., Bagni, C., Bayés, À., Biederer, T., Brose, N., Chua, J.J.E., Dieterich, D.C., Gundelfinger, E.D., Hoogenraad, C., Huganir, R.L., Jahn, R., Kaeser, P.S., Kim, E., Kreutz, M.R., Mcpherson, P.S., Neale, B.M., O'connor, V., Posthuma, D., Ryan, T.A., Sala, C., Feng, G., Hyman, S.E., Thomas, P.D., Smit, A.B., and Verhage, M. (2019). SynGO: An Evidence-Based, Expert-Curated Knowledge Base for the Synapse. Neuron 103, 217-234.e214. (2014). Synapse elimination and learning rules co-regulated by MHC class I H2-Db. Nature 509, 195-200.

Lesh, T.A., Careaga, M., Rose, D.R., Mcallister, A.K., Van De Water, J., Carter, C.S., and Ashwood, P. (2018). Cytokine alterations in first-episode schizophrenia and bipolar disorder: relationships to brain structure and symptoms. Journal of Neuroinflammation 15, 165.

Lin, H.-C., He, Z., Ebert, S., Schörnig, M., Santel, M., Nikolova, M.T., Weigert, A., Hevers, W., Kasri, N.N., Taverna, E., Camp, J.G., and Treutlein, B. (2021). NGN2 induces diverse neuron types from human pluripotency. Stem Cell Reports 16, 2118-2127.

Lins, B.R., Hurtubise, J.L., Roebuck, A.J., Marks, W.N., Zabder, N.K., Scott, G.A., Greba, Q., Dawicki, W., Zhang, X., Rudulier, C.D., Gordon, J.R., and Howland, J.G. (2018). Prospective Analysis of the Effects of Maternal Immune Activation on Rat Cytokines during Pregnancy and Behavior of the Male Offspring Relevant to Schizophrenia. eNeuro 5. the pathophysiology of autism spectrum disorder. Molecular Psychiatry 23, 1001-1013.

466 Mcallister, A.K. (2014). Major histocompatibility complex I in brain development and schizophrenia. 
Meyer, U. (2019). Neurodevelopmental Resilience and Susceptibility to Maternal Immune Activation. Trends Neurosci 42, 793-806.

Mirabella, F., Desiato, G., Mancinelli, S., Fossati, G., Rasile, M., Morini, R., Markicevic, M., Grimm, C., Amegandjin, C., Termanini, A., Peano, C., Kunderfranco, P., Di Cristo, G., Zerbi, V., Menna, E., Lodato, S., Matteoli, M., and Pozzi, D. (2021). Prenatal interleukin 6 elevation increases glutamatergic synapse density and disrupts hippocampal connectivity in offspring. Immunity 54, 2611-2631.e2618.

Monteiro, S., Roque, S., Marques, F., Correia-Neves, M., and Cerqueira, J.J. (2017). Brain interference: Revisiting the role of IFNy in the central nervous system. Progress in Neurobiology 156, 149-163.

Mueller, F.S., Polesel, M., Richetto, J., Meyer, U., and Weber-Stadlbauer, U. (2018). Mouse models of maternal immune activation: Mind your caging system! Brain Behav Immun 73, 643-660.

Mueller, F.S., Richetto, J., Hayes, L.N., Zambon, A., Pollak, D.D., Sawa, A., Meyer, U., and Weber-

Mueller, F.S., Scarborough, J., Schalbetter, S.M., Richetto, J., Kim, E., Couch, A., Yee, Y., Lerch, J.P., Vernon, A.C., Weber-Stadlbauer, U., and Meyer, U. (2021). Behavioral, neuroanatomical, and molecular correlates of resilience and susceptibility to maternal

Onwordi, E.C., Halff, E.F., Whitehurst, T., Mansur, A., Cotel, M.-C., Wells, L., Creeney, H., Bonsall, D., Rogdaki, M., Shatalina, E., Reis Marques, T., Rabiner, E.A., Gunn, R.N., Natesan, S., Vernon, A.C., and Howes, O.D. (2020). Synaptic density marker SV2A is reduced in schizophrenia patients and unaffected by antipsychotics in rats. Nature Communications 11, 246. 
Osimo, E.F., Beck, K., Reis Marques, T., and Howes, O.D. (2019). Synaptic loss in schizophrenia: a meta-analysis and systematic review of synaptic protein and mRNA measures. Molecular Psychiatry 24, 549-561.

Pawlowski, M., Ortmann, D., Bertero, A., Tavares, J.M., Pedersen, R.A., Vallier, L., and Kotter, M.R.N. (2017). Inducible and Deterministic Forward Programming of Human Pluripotent Stem Cells into Neurons, Skeletal Myocytes, and Oligodendrocytes. Stem Cell Reports 8, 803-812.

Pekala, M., Doliwa, M., and Kalita, K. (2021). Impact of maternal immune activation on dendritic spine development. Dev Neurobiol 81, 524-545.

Rasmussen, J.M., Graham, A.M., Gyllenhammer, L.E., Entringer, S., Chow, D.S., O'connor, T.G., Fair, D.A., Wadhwa, P.D., and Buss, C. (2021). Neuroanatomical Correlates Underlying the Association Between Maternal Interleukin 6 Concentration During Pregnancy and Offspring Fluid Reasoning Performance in Early Childhood. Biol Psychiatry Cogn Neurosci Neuroimaging.

Ripke, S., Neale, B.M., Corvin, A., Walters, J.T.R., Farh, K.-H., Holmans, P.A., Lee, P., BulikSullivan, B., Collier, D.A., Huang, H., Pers, T.H., Agartz, I., Agerbo, E., Albus, M., Alexander, M., Amin, F., Bacanu, S.A., Begemann, M., Belliveau Jr, R.A., Bene, J., Bergen, S.E., Bevilacqua, E., Bigdeli, T.B., Black, D.W., Bruggeman, R., Buccola, N.G., Buckner, R.L., Byerley, W., Cahn, W., Cai, G., Campion, D., Cantor, R.M., Carr, V.J., Carrera, N., Catts, S.V., Chambert, K.D., Chan, R.C.K., Chen, R.Y.L., Chen, E.Y.H., Cheng, W., Cheung, E.F.C., Ann Chong, S., Robert Cloninger, C., Cohen, D., Cohen, N., Cormican, P., Craddock, N., Crowley, J.J., Curtis, D., Davidson, M., Davis, K.L., Degenhardt, F., Del Favero, J., Demontis, D., Dikeos, D., Dinan, T., Djurovic, S., Donohoe, G., Drapeau, E., Duan, J., Dudbridge, F., Durmishi, N., Eichhammer, P., Eriksson, J., Escott-Price, V., Essioux, L., Fanous, A.H., Farrell, M.S., Frank, J., Franke, L., Freedman, R., Freimer, N.B., Friedl, M., Friedman, J.I., Fromer, M., Genovese, G., Georgieva, L., Giegling, I., Giusti-Rodríguez, P., 
Godard, S., Goldstein, J.I., Golimbet, V., Gopal, S., Gratten, J., De Haan, L., Hammer, C., Hamshere, M.L., Hansen, M., Hansen, T., Haroutunian, V., Hartmann, A.M., Henskens, F.A., Herms, S., Hirschhorn, J.N., Hoffmann, P., Hofman, A., Hollegaard, M.V., Hougaard, D.M., Ikeda, M., Joa, I., et al. (2014). Biological insights from 108 schizophrenia-associated genetic loci. Nature 511, 421-427.

Rudolph, M.D., Graham, A.M., Feczko, E., Miranda-Dominguez, O., Rasmussen, J.M., Nardos, R., Entringer, S., Wadhwa, P.D., Buss, C., and Fair, D.A. (2018). Maternal IL-6 during pregnancy can be estimated from newborn brain connectivity and predicts future working memory in offspring. Nat Neurosci 21, 765-772.

Sekar, A., Bialas, A.R., De Rivera, H., Davis, A., Hammond, T.R., Kamitaki, N., Tooley, K., Presumey, J., Baum, M., Van Doren, V., Genovese, G., Rose, S.A., Handsaker, R.E., Schizophrenia Working Group of the Psychiatric Genomics, C., Daly, M.J., Carroll, M.C.,

Shatz, C.J. (2009). MHC class I: an unexpected role in neuronal plasticity. Neuron 64, 40-45.

Shi, J., Levinson, D.F., Duan, J., Sanders, A.R., Zheng, Y., Pe'er, I., Dudbridge, F., Holmans, P.A., Whittemore, A.S., Mowry, B.J., Olincy, A., Amin, F., Cloninger, C.R., Silverman, J.M., Stevens, B., and Mccarroll, S.A. (2016). Schizophrenia risk from complex variation of complement component 4. Nature 530, 177-183.

Shum, C., Dutan, L., Annuario, E., Warre-Cornish, K., Taylor, S.E., Taylor, R.D., Andreae, L.C.,

540 Buckley, N.J., Price, J., Bhattacharyya, S., and Srivastava, D.P. (2020). $\Delta 9$ -

541 tetrahydrocannabinol and 2-AG decreases neurite outgrowth and differentially affects

542 ERK1/2 and Akt signaling in hiPSC-derived cortical neurons. Molecular and Cellular Neuroscience 103, 103463. 
544 Smith, S.E., Li, J., Garbett, K., Mirnics, K., and Patterson, P.H. (2007). Maternal immune activation alters fetal brain development through interleukin-6. J Neurosci 27, 10695-10702.

546 Urakubo, A., Jarskog, L.F., Lieberman, J.A., and Gilmore, J.H. (2001). Prenatal exposure to maternal infection alters cytokine expression in the placenta, amniotic fluid, and fetal brain. Schizophr Res 47, 27-36.

Warre-Cornish, K., Perfect, L., Nagy, R., Duarte, R.R.R., Reid, M.J., Raval, P., Mueller, A., Evans, A.L., Couch, A., Ghevaert, C., Mcalonan, G., Loth, E., Murphy, D., Powell, T.R., Vernon, A.C., Srivastava, D.P., and Price, J. (2020). Interferon-y signaling in human iPSC-derived neurons recapitulates neurodevelopmental disorder phenotypes. Science Advances 6, eaay9506.

Weir, R.K., Forghany, R., Smith, S.E., Patterson, P.H., Mcallister, A.K., Schumann, C.M., and Bauman, M.D. (2015). Preliminary evidence of neuropathology in nonhuman primates prenatally exposed to maternal immune activation. Brain Behav Immun 48, 139-146.

Yilmaz, M., Yalcin, E., Presumey, J., Aw, E., Ma, M., Whelan, C.W., Stevens, B., Mccarroll, S.A., and Carroll, M.C. (2021). Overexpression of schizophrenia susceptibility factor human complement C4A promotes excessive synaptic loss and behavioral changes in mice. Nat

561 Zakharenko, S., Chang, S., O'donoghue, M., and Popov, S.V. (1999). Neurotransmitter secretion along growing nerve processes: comparison with synaptic vesicle exocytosis. J Cell Biol 144, 507-518.

564 Zhang, Y., Pak, C., Han, Y., Ahlenius, H., Zhang, Z., Chanda, S., Marro, S., Patzke, C., Acuna, C., 565 Covy, J., Xu, W., Yang, N., Danko, T., Chen, L., Wernig, M., and Südhof, T.C. (2013). Rapid 566 single-step induction of functional neurons from human pluripotent stem cells. Neuron 78, 785-798. 
bioRxiv preprint doi: https://doi.org/10.1101/2021.12.15.472810; this version posted December 16,2021 . The copyright holder for this preprint (which was not certified by peer review) is the author/funder, who has granted bioRxiv a license to display the preprint in perpetuity. It is made

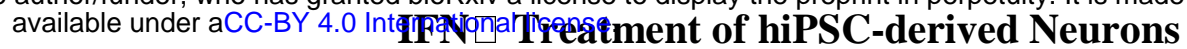

568 Zhang, Z., and Van Praag, H. (2015). Maternal immune activation differentially impacts mature and adult-born hippocampal neurons in male mice. Brain Behav Immun 45, 60-70. 
571 Figure 1. Analysis of synaptic gene ontology in immature iPSC-neurons treated with IFNy. (A

572 \& B) SynGO synaptic gene ontology analyses of down-regulated DEG in D30 neurons acutely 573 exposed to IFNy. The sunburst plots represent synaptic annotated ontologies for CC (B) and BP (A) 574 terms. The key colour scale indicates -log10 FDR adjusted p-values. (A) Significantly enriched CC 575 ontologies include synapse (red) presynaptic (magenta) clusters. (B) Annotated BP terms include 576 synaptic (magenta), presynaptic (red) and signalling (blue) terms. (C), (D) Plots of synaptic GO

577 output showing the $3 \mathrm{CC}(\mathrm{C})$ and $5 \mathrm{BC}$ (D) significantly (FDR-adjusted) enriched terms for D30 IFNY 578 exposed neurons. The bar length indicates the number of genes, the order of each bar and numbers 579 adjacent to each are the FDR adj. P-value. Analysis of data previously published in Warre-Cornish 580 et al., 2020.

582 Figure 2. Exposure of neurons to IFN $\square$ results in increased $\mathbf{M H C l}$ (A) Schematic of Opti-OX 583 neural induction and IFN $\square$ exposure at day 3 for 24 hours. (B) Detailed view of a cell body, nucleus, 584 and $\mathrm{MHCl}$ puncta within the nucleus. (C) ICC for $\mathrm{MHCl}$. The top row shows control cells, the bottom 585 row shows cells exposed to IFN $\square$ at day 3 for $24 \mathrm{hrs}$. The $\mathrm{MHCl}$ Fire LUT pseudo colour shows 586 higher intensity with warmer colours and lower intensity with cooler colours. The gray values 587 corresponding to the colours are shown on the calibration bar on the right. (D-H) b Scatter plots of $588 \mathrm{MHCl}$ intensity in control and IFN $\square$-exposed neurons. The horizontal bars represent the mean, the 589 error bars represent the standard deviation. Each point in the intensity plots represents the mean 590 intensity of one field of view i.e., image, of the respective object. The different data point colours 591 represent biological replicates with different passage numbers. The IFN $\square$ and control were compared using an unpaired T-test, where $\mathrm{N}=3$ and **** indicates $\mathrm{P}<0.0001$, *** indicates $0.001<\mathrm{P}>0.001,{ }^{* *}$ indicates $0.001<\mathrm{P}>0.01$, and ns indicates $\mathrm{P} \geq 0.05$ (not significant). 
598 the cytoplasm. (B) IHC for synapsin I. The top row shows control cells, the bottom row shows cells

599 exposed to IFN $\square$ at day 3 for 24hrs. The SYN1 Fire LUT pseudo colour shows higher intensity with

600 warmer colours and lower intensity with cooler colours. Detailed view shown on right. The gray

601 values corresponding to the colours are shown on the calibration bar on the right. (C-F) Scatter plots

602 of synapsin I intensity in control and IFN $\square$-exposed neurons. The horizontal bars represent the

603 mean, the error bars represent the standard deviation. Each point in the intensity plots represents

604 the mean intensity of one field of view i.e., image, of the respective object. The different data point

605 colours represent biological replicates with different passage numbers. The IFN $\square$ and control were

606 compared using an unpaired t-test, where $\mathrm{N}=3$ and ** indicates $\mathrm{d} 0.001<\mathrm{P}>0.01$, * indicates

$607 \quad 0.01<P>0.05$, and ns indicates $P \geq 0.05$ (not significant).

608

609 Figure 4. Effects of acute IFN $\square$ treatment of gene expression in immature neurons. Bar graphs

610 of relative expression of selected genes, showing increased $H L A-B$ and $C 4 A$ expression in IFN $\square$ -

611 exposed neurons. The bars indicate the $\log \left(2^{-\Delta \Delta C T}\right)$, which indicates the expression relative to

612 housekeepers and normalized to the housekeepers of the control samples (See methods for

613 details.) (A) Expression in Day 4 NGN2-iNs exposed at day 3. $\mathrm{N}=3$. ${ }^{* * * *}$ indicates $\mathrm{P}<0.0001,{ }^{* * *}$

614 indicates $P=0.000291$ (unpaired t-test). (B) Expression in day 27 conventionally differentiated

615 127_CTM iPSC line NPCs exposed at day 26. *** indicates $\mathrm{P}<0.0001$, ** indicates

$616 P=0.002947$ (unpaired t-test). The bar represents the mean, the error bars represent the standard

617 deviation. Points of the same colour represent the same biological replicate. 

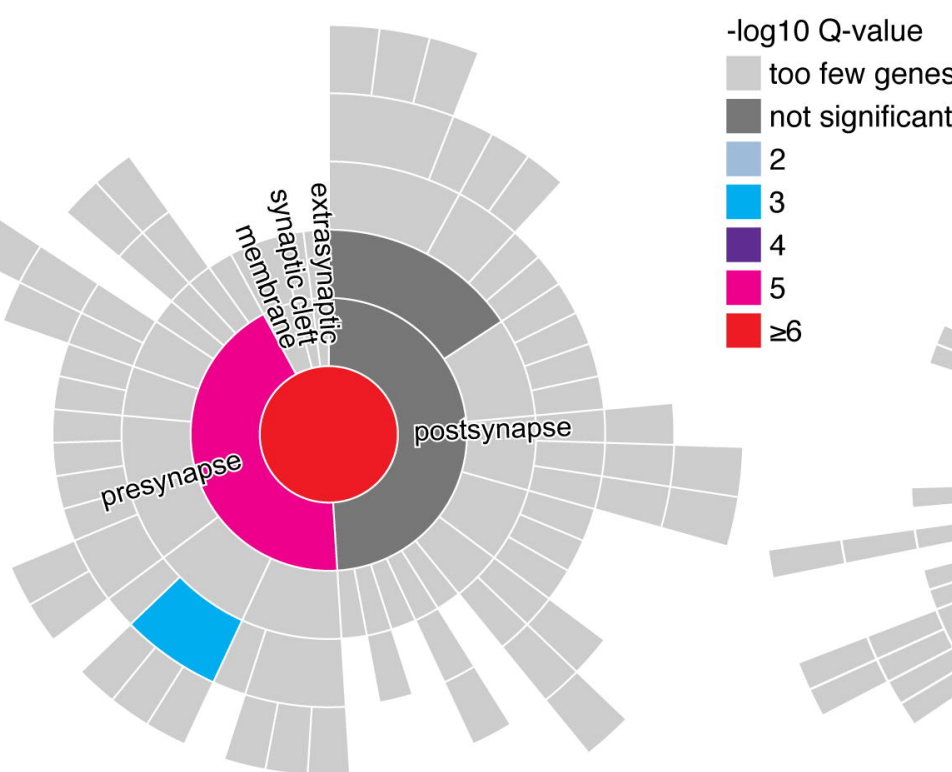

(C)
\&
¿
0
0
0
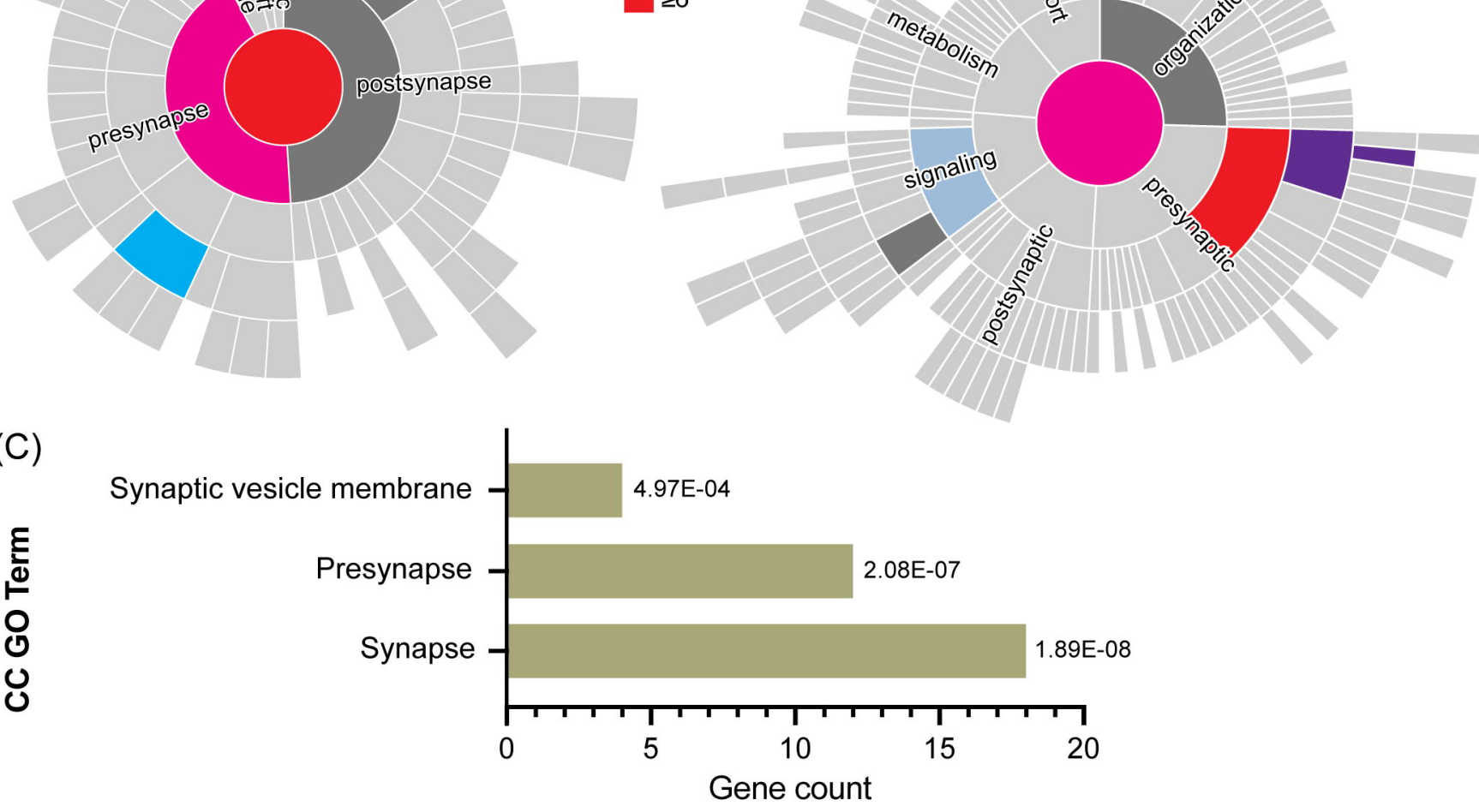
(D)
Trans-synaptic signalling Regulation of synaptic

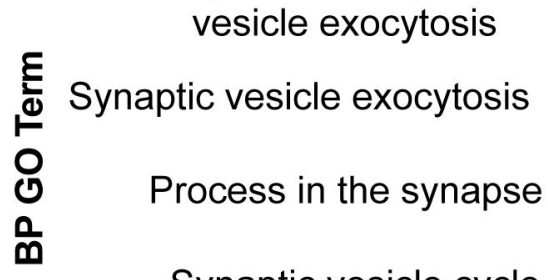

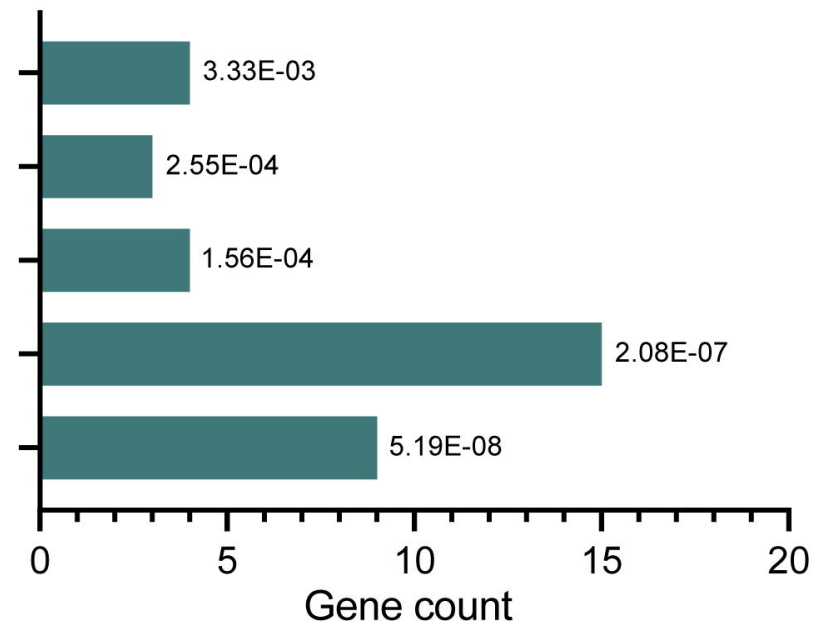


(which was not certified by peer review) is the author/funder, whoh) as granted bioRxiv a license to display the preprint in perpetuit
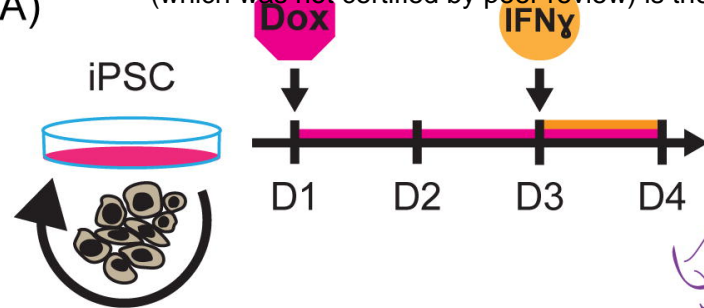

\section{D4 Neurons}

\section{$\mathrm{MHCl}$ DAPI}

(C)

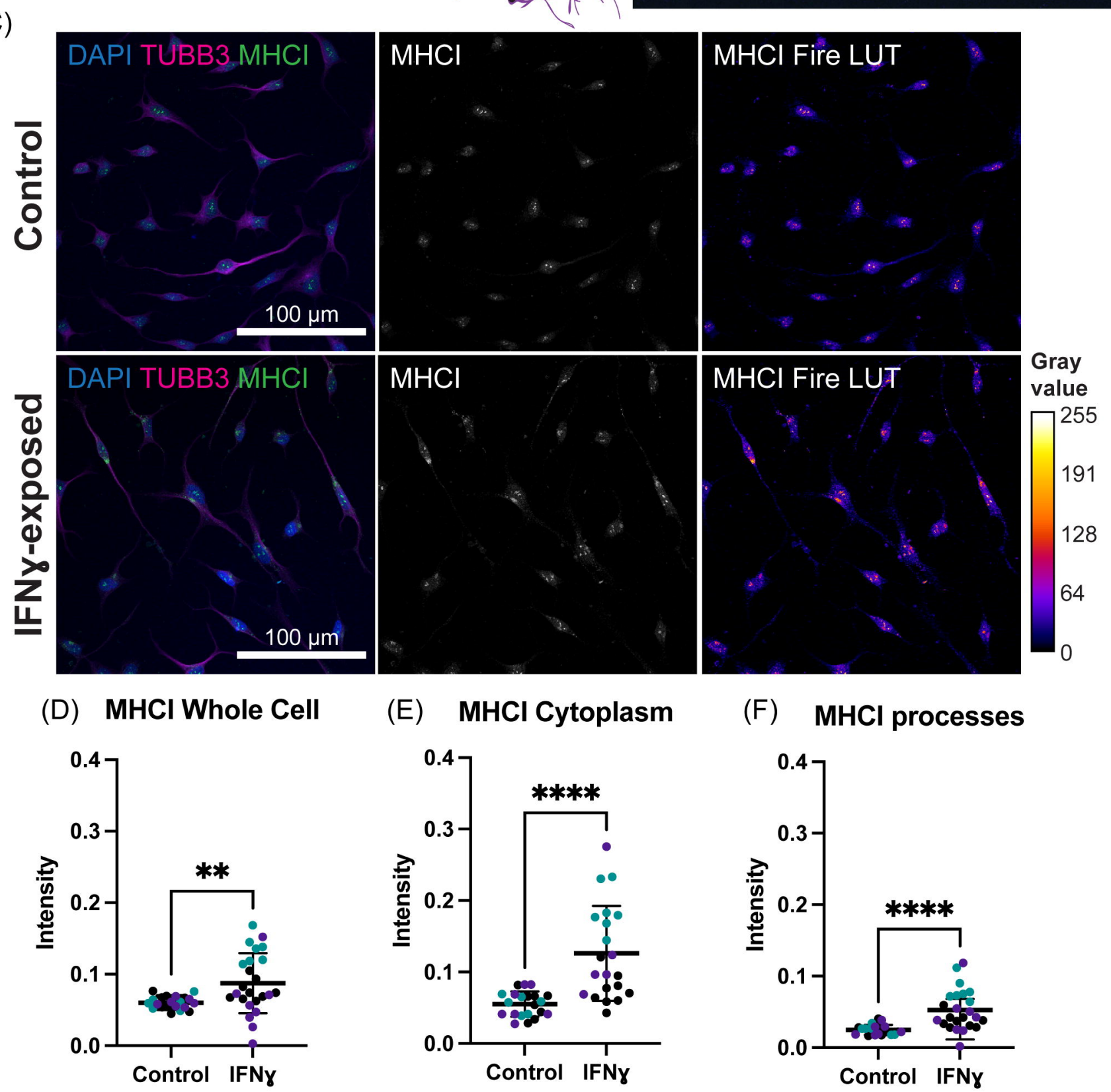

D4

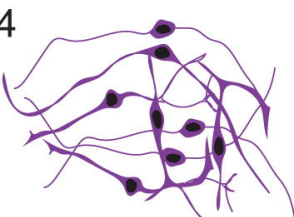

(D) $\mathrm{MHCl}$ Whole Cell

(E) MHCl Cytoplasm

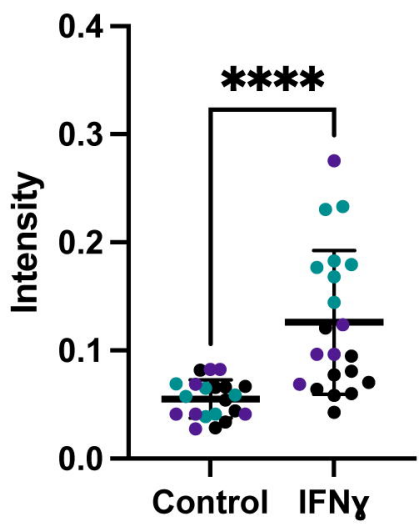

(F) $\mathrm{MHCl}$ processes

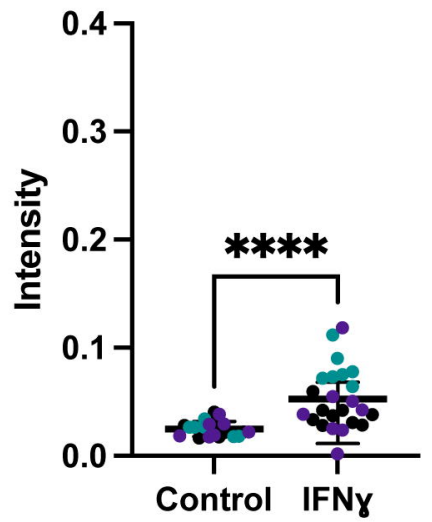

(G) MHCl Cell Body

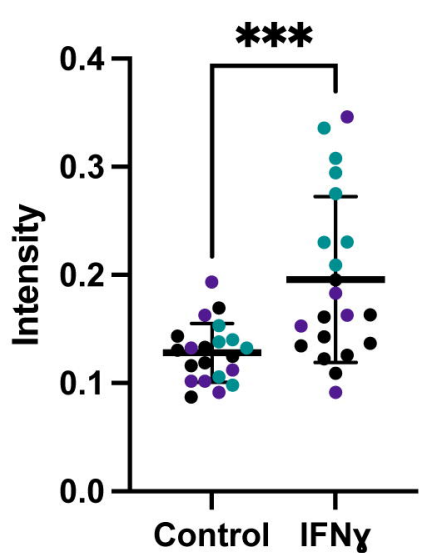

(H) MHCl Nuclei

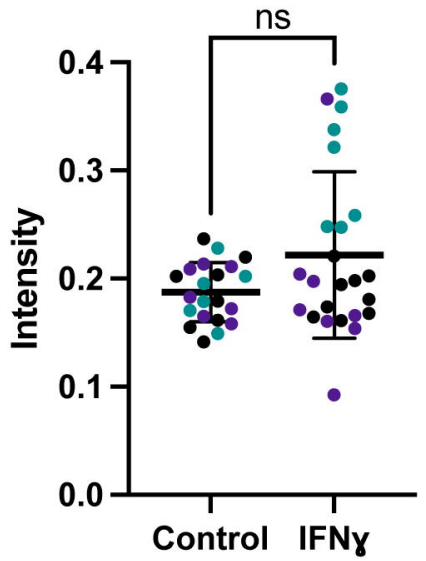




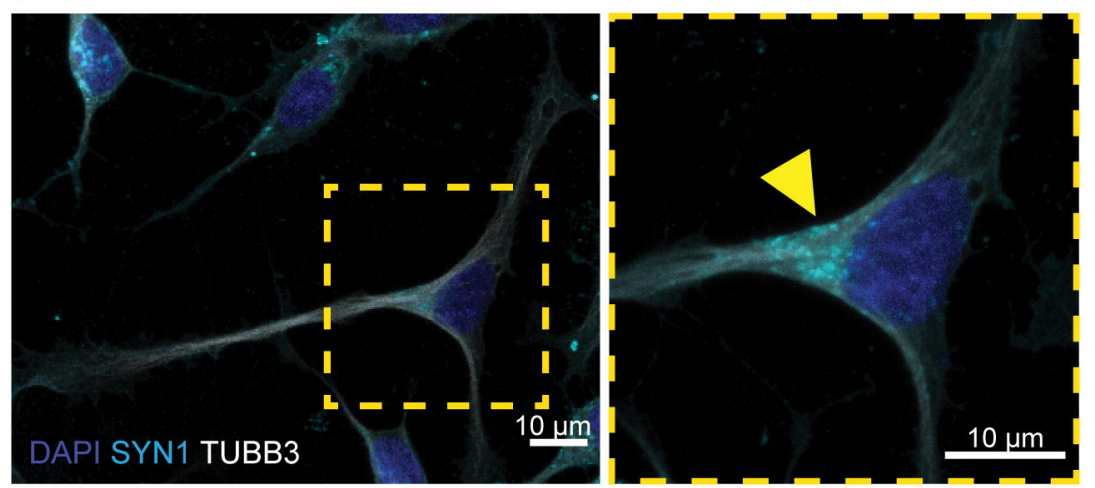

(B)
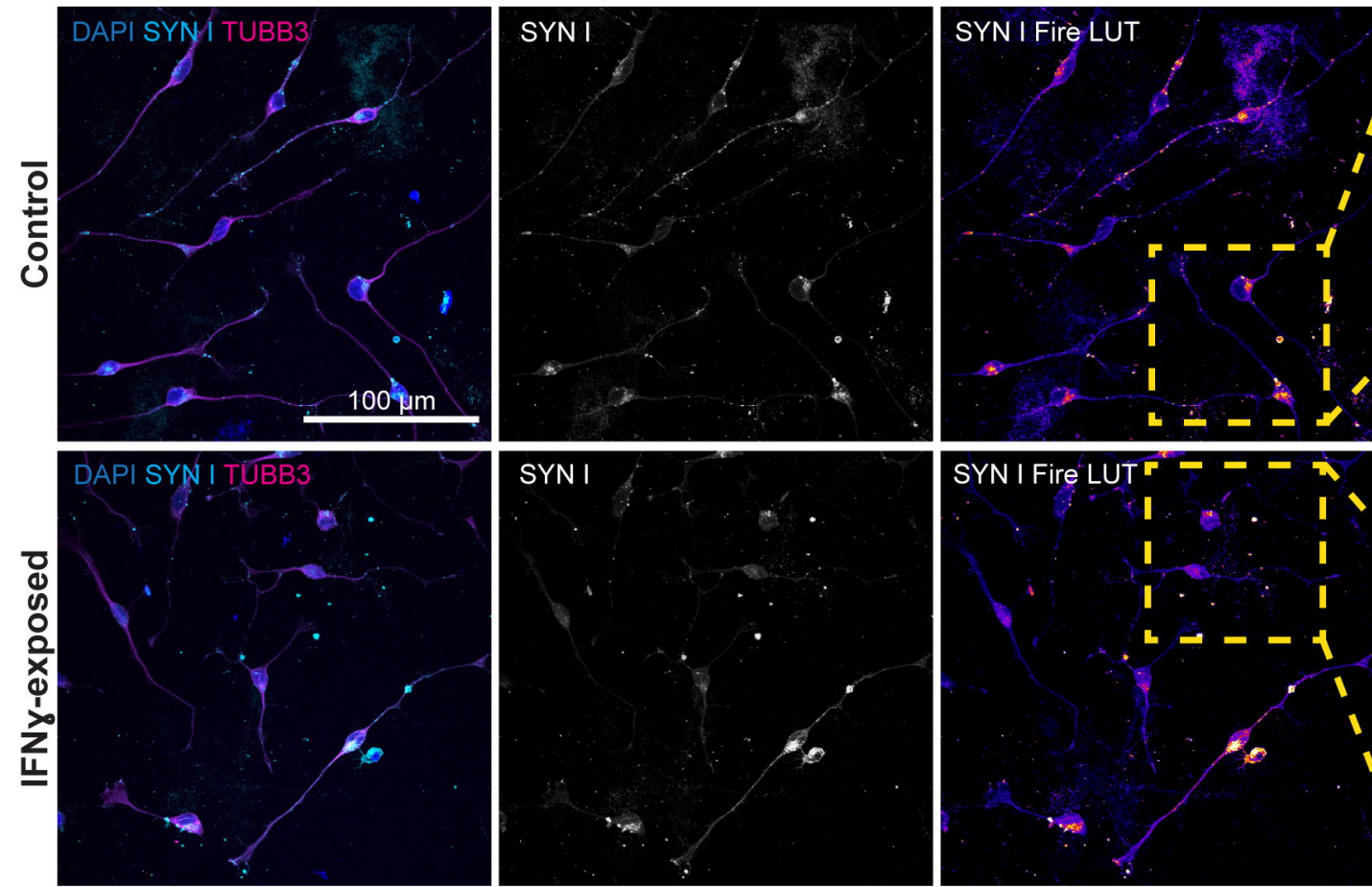

\section{Control}

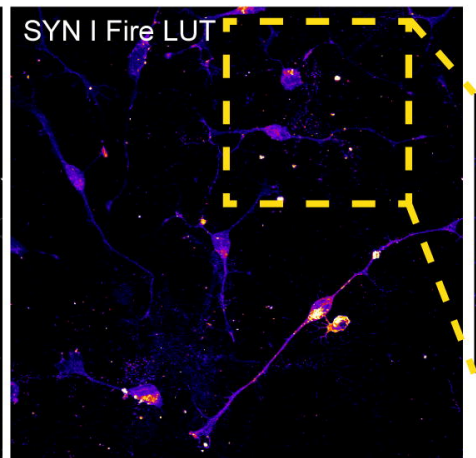

$\begin{array}{llllll}\text { Gray } & 0 & 64 & 128 & 191 & 255\end{array}$ value

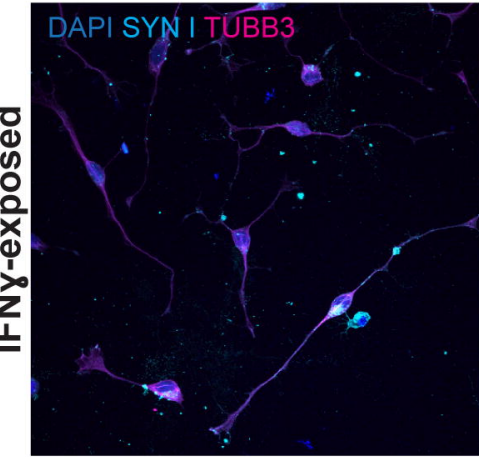

\section{IFNy-exposed}

(C)

SYN I Whole Cell

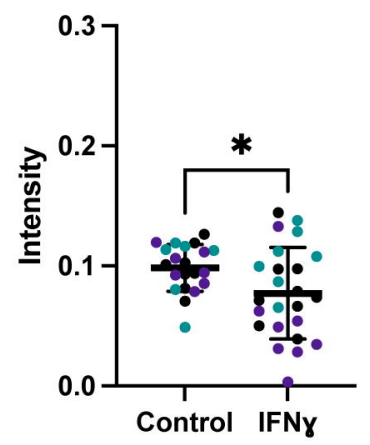

(D)

SYN I Cytoplasm

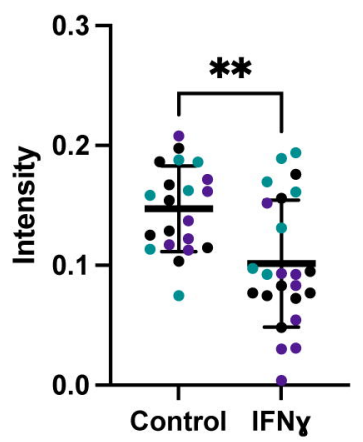

(E)

SYN I Processes

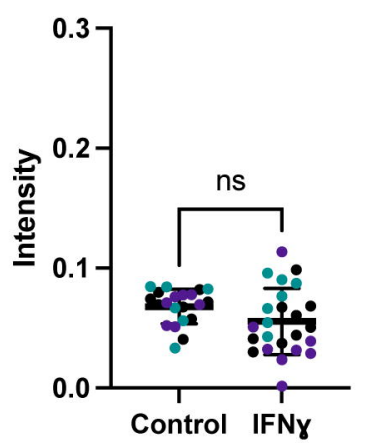

(F)

\section{SYN I Cell Body}

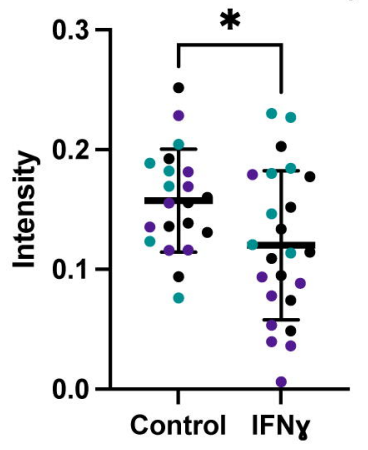


(A)

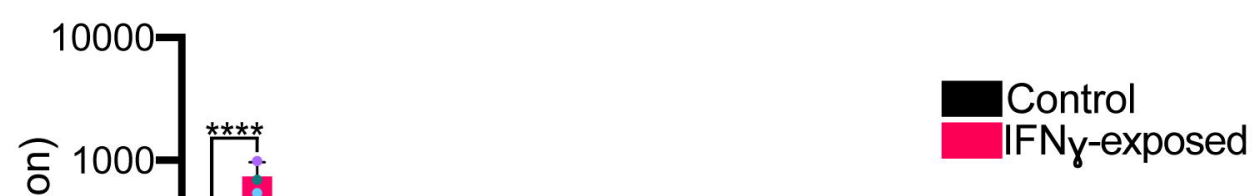

(B)

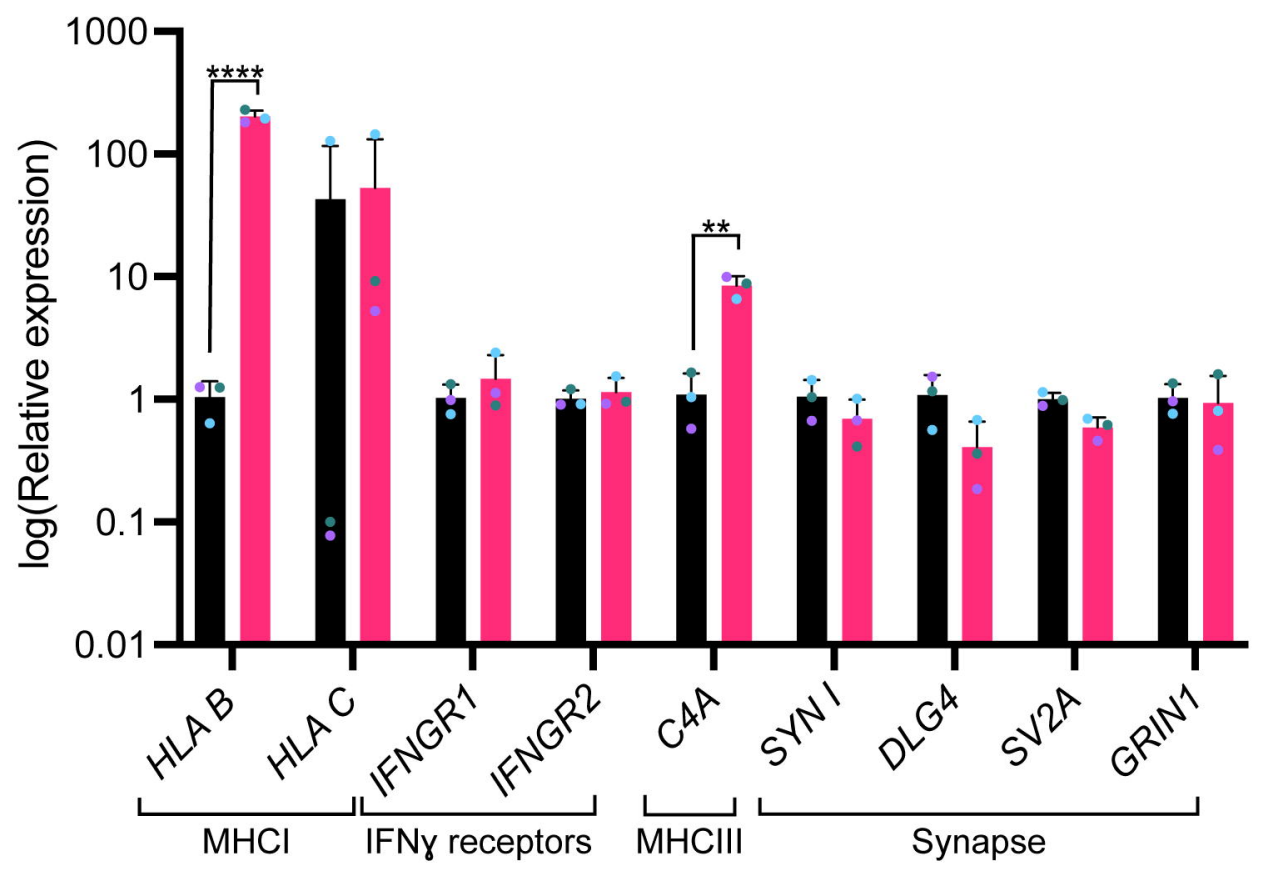

